\title{
EXPERIMENTAL INVESTIGATION OF A SOLAR STILL-COLLECTOR SYSTEM FOR SOLAR DESALINATION IN RURAL AND DESERT COMMUNITIES
}

\section{Mahmoud Ahmed Elnono*}

\begin{abstract}
A passive solar still (single-slope solar still) was connected to a flat plate collector, to be an active one, through a heat exchanger on the bottom of the still basin, and a small size pump to circulate the working fluid (distilled water) in a closed and separate loop from the basin water in order to transfer extra thermal energy to the solar still for improving the productivity of the solar still, as well as avoiding corrosive effects on the collector material or forming scales which clog the collector due to the natural chemicals of salty, brackish, or contaminated water which is the main problem of direct augmentation. The system was designed, manufactured and tested at Ag. Eng. Dept., Fac. of Ag., Ain Shams Univ., Cairo, Egypt $\left(\phi=30^{\circ} \mathrm{N}\right)$. A complete description of the designed system is presented. Various experiments were carried out. Measurements were taken on hourly basis during the daylight hours for several days of three months (July, August and September, 2011),for the active solar still system and the solar still alone. The experiments performed at $0.05 \mathrm{~m}$ water depth using saline water (28608 ppm). A comparative analysis between the experimental results of two solar stills showed that the average daily production rate (Aug., 2011) of the active solar still was increased by about $45.22 \%$, it was around 1.83 times higher than the passive solar still. The thermal efficiency of the active solar still was lower than the passive solar still by an average of 3.9\%. Economic analysis was also made and payback period of the experimental setup was discussed.
\end{abstract}

Key Words: Solar desalination, solar stills, performance, productivity enhancement, thermal efficiency.

*Ag. Eng. Dept., Fac. of Ag., Ain Shams Univ., Cairo, Egypt. 


\section{INTRODCTION}

$\mathrm{W}$ ater is the source of life, but there is a limited supply of pure water on earth. Although $71 \%$ of the earth's surface is covered by water, only $2.5 \%$ of the earth's water is fresh, and clean safe drinking water is not available to over 1.2 billion people (28 percent of the world population $\left.{ }^{(*)}\right)$.That means the shortage of pure drinking water is an urgent problem in some countries in the world, and it is continuously increasing due to population growth and changes in the weather conditions especially in arid and sime-arid zone. Therefore, desalination which refers to any of several processes that remove some amount of salt and other minerals from water, seems to be the most suitable solution for that problem. However, the standard desalination techniques like multi-stage flash, multi-effect, vapor compression and reverse osmosis are only reliable for large capacity ranges (Hou et. al. 2005). These technologies are expensive for small amount of fresh water, and consume a large amount of energy derived from oil and natural gas as heat and electricity, which have a negative impact on the environment due to emitting harmful emissions such as $\mathrm{CO}_{2}$ and sulphur that cause greenhouse effect which lead to contamination and warming of the earth. Moreover, they can not be used in locations of rural and desert communities where there are limited maintenance facilities and energy supply. Consequently, solar desalination is the best alternative to supply some rural and desert communities in Egypt with fresh water for many reasons such as : (1) solar energy is well known as a clean and inexhaustible energy source; (2) Egypt has an average solar energy of 5 to $8 \mathrm{~kW} . \mathrm{h} / \mathrm{m}^{2}$ per day, and sunshine duration per year extends to about 3000 hours (Sayigh (1977) and El-Sayed (1993),cited by El-shahat (1999)); (3) Egypt has long coastal site where seawater is normally available; and (4) Egypt has brackish and contaminated groundwater in the desert communities where most people rely on. All of these reasons make the utilization technologies of solar desalination acceptable for the purpose of 
producing clean, pure water for human consumption (or irrigation) in Egypt where the availability of fresh pure water is limited and affecting millions of people.

One simple technology to desalinate water using solar energy is the solar still. Many theoretical and experimental studies about solar still were carried out by researchers worldwide. Aybar (2007) defined a solar still as a simple device to desalinate impure water like brackish or saline water to get potable / fresh distilled water, using solar energy as a fuel, for various applications. The purpose of a solar still is to capture the evaporated water by condensing it onto a cool surface. Increasing water temperature and the area of water in contact with air can accelerate the rate of evaporation. There are different types of solar still systems and designs that can be found in literature. He classified solar distillation systems into two groups in terms of energy supply. They are passive and active stills. The passive solar still systems are conventional solar still systems which use solar energy as the only source of thermal energy. In active solar stills, extra thermal energy is given to the passive solar still for faster evaporation. This extra thermal energy may be obtained from a solar collector, or any available waste thermal energy. Voropoulos el al. (2001) reported that by coupling of the solar still with thermal storage, heated by flat plate collectors, the yield increased by two times than that of the solar still only. Badran et al. (2005) investigated a basin-type solar still and a conventional flat-plate collector which were connected together in order to study the effect of augmentation on still productivity. They found that the mass of distilled water using augmentation was increased by $52 \%$ in the case of salt water as a feed. Another experimental investigation was carried out by Badran and Al-Tahaineh (2005) to study the effect of different parameters, such as water depth, direction of still and solar radiation on the still productivity. They found that coupling of a solar collector with a still has increased the productivity by $36 \%$. Also the 
increase of water depth has decreased the productivity, while the still productivity was found to be proportional to the solar radiation intensity.

In Egypt, Abdel-Ghafar (1989), cited by Radwan et. al. (2009), designed a solar still in Alexandria. It was fitted with a mirror on still side walls. He found that the maximum observed basin water temperatures were 53 $\mathrm{C}^{\mathrm{o}}$ and $56 \mathrm{C}^{\mathrm{o}}$ in June and July, respectively, and $2 \mathrm{~L} / \mathrm{m}^{2}$.day of distilled water was obtained. Radwan et. al. (2009) developed, analyzed and tested a single slope solar still for sea water distillation. They found that the average productivity in August was $0.317 \mathrm{~L} / \mathrm{m}^{2}$.day which was the highest average distilled production, comparing with May and July. Therefore, the main objectives of the present work were:

1- Design and manufacture a solar still-collector system for improving the productivity, as well as avoiding the problem of direct augmentation.

2- Test the active solar still system and the solar still alone under local conditions.

3- Investigate the performance of the above two systems by determining the hourly production rate, the daily (accumulated) production, and the thermal efficiency.

4- Make economic analysis for the experimental setup to estimate the payback period.

\section{MATERIALS AND METHODS}

\section{1) Experimental Setup (A Complete Description):}

Fig. (1) shows the schematic diagram of the constructed active solar still system. It was designed, manufactured and tested at Ag. Eng. Dept., Fac. of Ag., Ain Shams Univ., Cairo, $\operatorname{Egypt}\left(\phi=30^{\circ} N\right)$. It consists of the following main components: solar still, flat-plate collector, and small size pump. 


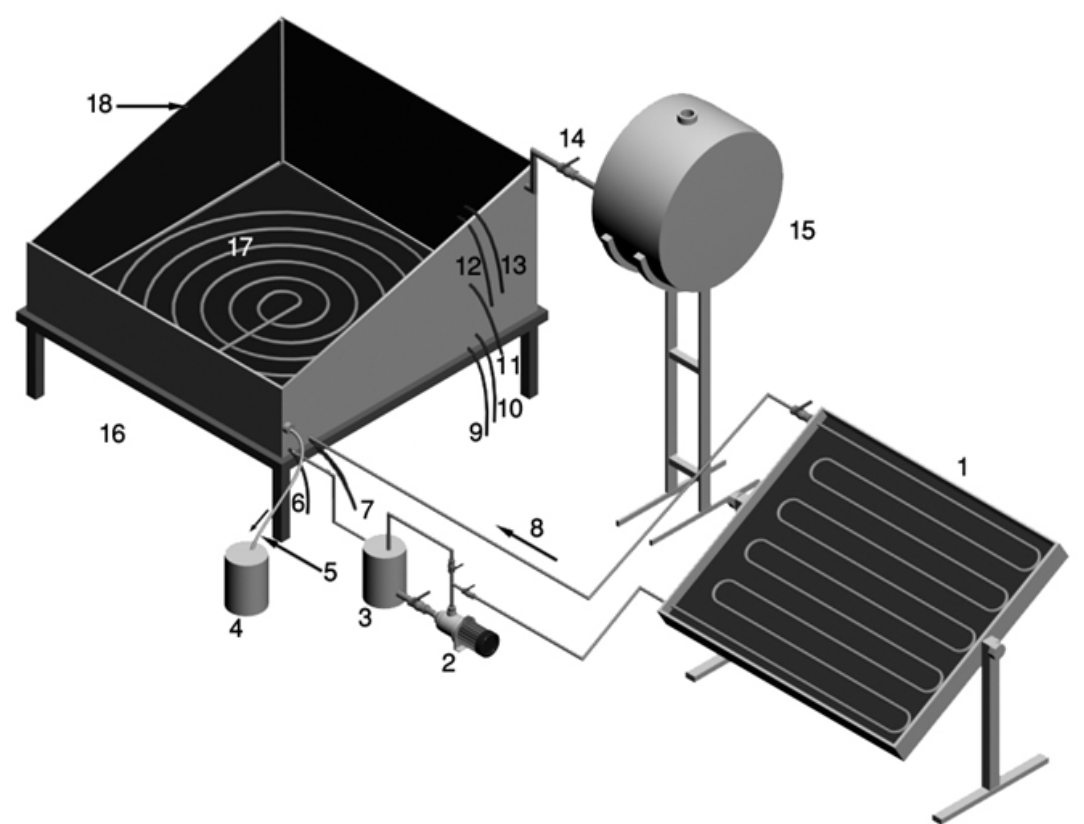

1-Flat plate collector

10- Tw

2-Water pump

11- Tv

3- Water vessel

4- Distilled water

12- Tgi

5-Plastic pipe to connect distillation trough to the external jar

13- Tgo

14- Feed valve

15- Saline water feed tank

6- Texo

7-Texi

8-Hot water from the flat plat collector to the solar still

16- Solar still

17- Heat exchanger

9- Tb

18- Condensations glass cover

Fig. (1): Schematic diagram of the constructed active solar still system

\section{a- Solar Still:}

A single-slope, basin-type solar still (passive solar still) was manufactured. It was made of steel-sheet of $1.5 \mathrm{~mm}$ thickness, and had a square basin area of $1 \mathrm{~m} \times 1 \mathrm{~m}$. The lower height (front side) of the basin was $0.27 \mathrm{~m}$ to accommodate different water depths and fix the distillation trough. The height of the rear side of the basin was $0.85 \mathrm{~m}$. The sides and bottom of the still were coated from inside by ordinary matt black paint in order to absorb more solar radiation and increase the gained energy. The basin and side walls were insulated with $25 \mathrm{~mm}$ of glass wool $(0.038$ 
$\mathrm{W} / \mathrm{m} . \mathrm{C}^{\mathrm{o}}$ thermal conductivity - Howell, et. al., 1982) to reduce the heat losses. A sheet of clear glass cover of $6 \mathrm{~mm}$ thickness was hold on the top of the solar still at inclination angle of $30^{\circ}$ with respect to the horizontal axis $\left(30^{\circ} \mathrm{N}\right.$ latitude of Cairo-zone). It was hold using Binder clips (No. 977112- 1-5/8 inch width). A rubber gasket was placed between the glass and the still frame. The contact surfaces between the glass cover, rubber gasket and still frame were sealed by silicone rubber sealant (made in Japan) to prevent vapor from leakage to outside. A catch trough was fixed at the end of the front vertical side (lower side) of the still basin with an enough slope to collect distilled water that had been run outside the solar still to an external container by connecting the trough with the container through a flexible hose. An inlet pipe was also fixed at the top of the rear side of the still which was connected to a feeding tank through a plastic pipe and control valve for feeding the solar still with saline / brackish water. A drainage pipe in the still bottom is also provided to flush the brine that develops on the bottom of the still as often as necessary depending on the distillation rate and brine depth to avoid the build-up of salt concentration to a level that deposits would be occurred. Holes were drilled in the side body of the solar still at the required position of the thermocouples as shown in fig. (1) to take the wire of respective thermocouple externally. The thermocouple wires (K-type) were fixed in the still body using Epoxy adhesives (made in U.S.A.). The whole unit is mounted on steel supporting frame $(1 \mathrm{mx} 1 \mathrm{mx} 1 \mathrm{~m})$.A heat exchanger is placed on the bottom of the still basin to couple the still with the collector which allows the pump to circulate the working fluid (distilled water) in a close and separate loop from the basin water in order to transfer extra thermal energy to the solar still for improving productivity, as well as avoiding corrosive effects on the collector material or forming scales which clog the collector due to the natural chemicals (e.g. sulfur, iron ...etc.) of salty, brackish, or contaminated water which is the main problem of direct augmentation. It was made of a copper tube $(1.0 \mathrm{~mm}$ thickness and $11 \mathrm{~mm}$ inner diameter, and had circulation serpentine pattern for more uniform temperature distribution in basin water. The solar still was oriented due south in order to receive maximum solar radiation throughout the year. 


\section{b-_Flat-Plate Collector:}

A flat-plate collector was constructed which had a surface area of $(1.2 \mathrm{~m} \mathrm{x}$ $1.0 \mathrm{~m})$. It consisted of cover plate, coolant tube, absorber plate, insulation and frame. The absorber was made of aluminum plate $(1.2 \mathrm{~m} \times 1.0 \mathrm{~m} \mathrm{X}$ $1.5 \mathrm{~mm}$ ) and coated with matt black paint to increase the absorptance of the plate to short-wave radiation in the solar spectrum and decrease longwave emission of the heated plate (Elsayed et. al., 1994). Heat is transferred to the working fluid (distilled water) through a copper tube of $1.0 \mathrm{~mm}$ thickness and $11.0 \mathrm{~mm}$ inner diameter which has serpentine pattern that gives the collector uniform fluid flow to avoid suffering from creating "hot spots" which lower the collector efficiency. A glass cover of $6.0 \mathrm{~mm}$ thickness is covered the absorber surface to reduce the convective and radiative heat loss from the top surface of the collector. The glass cover is tightly fixed, using aluminum frame and screws, to a wooden containment box of $2.5 \mathrm{~cm}$ thickness and $10 \mathrm{~cm}$ deep, for enclosing the absorber plate, copper serpentine tube and insulation. A glass wool insulation of $25 \mathrm{~mm}$ thickness is used to reduce the bottom and side thermal losses of the wooden containment box. The rubber seal is placed between the wooden box and the glass cover as well as between the glass and the aluminum frame. The outer sides and bottom of the containment box are also painted with matt black paint. Steel supporting is used to hold the collector, that is oriented due south, at an angel $30^{\circ}$ with respect to the horizontal. The collector has two external connections for inlet and outlet of the working fluid.

\section{c- Pump:}

An electric-centrifugal pump (VETD-made in China) was used to circulate the working fluid (distilled water) at a rate of about $1.0 \mathrm{~L} / \mathrm{min}$ in closed loop through the collector serpentine and the heat exchanger of the still under forced mode of operation (about $50 \mathrm{kPa}$ operating gauge pressure) to compensate the elevation difference between the pump and the solar collector, and the pressure drop in the heat exchanger, the collector tube, the piping arrangement and minor losses .And to insure pump self-priming and avoid air bleeding, it was advisable to use a small insulated vessel (5.0 litters-size ) with the pipe line that connect the external outlet connection of the heat exchanger with the intake mouth of 
the pump. The pump outlet was connected to the inlet connection of the flat plate collector by using two adjustment control valves as in fig.(1) to adjust the discharge of an average $1.0 \mathrm{~L} / \mathrm{min}$ to flow to the collector and the rest of the pump discharge was by-passed to the insulated vessel. The piping arrangement was also insulated using a glass wool insulation of 25 $\mathrm{mm}$ thickness to reduce thermal losses. The required electrical energy for pump operation could be calculated (by assuming the overall efficiency $=$ $75 \%$, and the pump operating time $=12 \mathrm{~h} /$ day) as the following:

$$
\begin{aligned}
\text { The actual required power }=\frac{P \times Q}{\eta_{\text {overall }}}= & \frac{50 \times 1000 \times 1}{1000 \times 60 \times 750 \times 0.75}=0.0015 \mathrm{hp} \\
& =0.0015 \times 0.7457=0.0011 \mathrm{~kW}
\end{aligned}
$$

The required electric energy $=0.0011 \times 12=0.0132 \quad \mathrm{kWh} /$ day

\section{2- Experimental Procedure and Instrumentation :}

Various experiments were carried out and the average measurements of temperatures, relative humidity, wind speed, solar intensity and distilled water production were taken on hourly basis for several days of three months ( July , August and September, 2011) for the active solar still system and the solar still alone during the daylight hours (from 7 a.m. to 6 p.m.). The experiments were performed at $0.05 \mathrm{~m}$ water depth using saline water (about $28608 \mathrm{ppm}, 2.5 \mathrm{gm}$ of sea salt per liter of tap water) as a feed. The following instruments were used to measure the different parameters:

a) Calibrated thermocouples (K-type, $\pm 0.4 \%$ error) and a digital thermometer (DM 6801A, made in China, measurement range -50 $\mathrm{c}^{\mathrm{o}}-199.9 \mathrm{C}^{\mathrm{o}}$, accuracy of $\pm 0.3 \%$ ) were used to measure the following temperatures : basin temperature $\left(\mathrm{T}_{\mathrm{b}}\right)$, water temperature $\left(\mathrm{T}_{\mathrm{w}}\right)$ at depth of $0.05 \mathrm{~m}$, inner glass temperature $\left(\mathrm{T}_{\mathrm{gi}}\right)$, outer glass temperature $\left(\mathrm{T}_{\mathrm{g}_{0}}\right)$, vapor temperature $\left(\mathrm{T}_{\mathrm{v}}\right)$, inlet temperature of the still heat exchanger $\left(\mathrm{T}_{\text {exi }}\right)$ and outlet temperature of the still heat exchanger $\left(\mathrm{T}_{\mathrm{exo}}\right)$.

b) Digital in-outdoor thermometer \& hygrometer, made in China, was used to measure the ambient temperature $\left(\mathrm{T}_{\mathrm{a}}\right)$ and relative humidity RH\%. 
c) Thermo - Anemometer (BKPRECISION, 731A, Made in CA, U.S.A., Range of $0.0-30.0 \mathrm{~m} / \mathrm{s}$, Accuracy of $\pm 3 \% \mathrm{FS}$ ) to measure the hourly wind velocity over the glass cover.

d) Graduated measuring cylinders were used to measure the hourly productivity of distilled water ( $\mathrm{m}$ ) with accuracy of $1.0 \mathrm{~mL}$.

e) Hourly total solar intensity on horizontal surface was obtained from Cairo Weather Station of Egyptian Meteorological Authority.

\section{3- Operational Efficiency of Solar Still:}

The performance of a solar still is judged by its operational thermal efficiency ( $\eta \mathrm{i})$, which is defined as the ratio of the evaporated heat transfer rate $\mathrm{q}_{\mathrm{e} w \mathrm{~g}}$ from water surface to glass cover in $\mathrm{W} / \mathrm{m} 2$ to the instantaneous solar radiation intensity $\mathrm{I}(\mathrm{t})$ in $\mathrm{W} / \mathrm{m}^{2}$ and it presented by ( Tiwari, 2002) as the following:

$$
\eta_{i}=\frac{\dot{q}_{e w-g}}{I(t)}=\frac{h_{e w-g}\left(T_{w}-T_{g}\right)}{I(t)}
$$

Where

$$
\begin{aligned}
& \mathrm{h}_{\mathrm{e} \mathrm{w}-\mathrm{g}}=\text { the evaporated heat transfer }\left(\mathrm{W} / \mathrm{m}^{2} \cdot \mathrm{K}^{\mathrm{O}}\right) \text {. } \\
& \mathrm{T}_{\mathrm{w}}=\text { the average water temperature }\left(\mathrm{K}^{\mathrm{o}}\right) \text {. } \\
& \mathrm{T}_{\mathrm{g}}=\text { the average glass temperature }\left(\mathrm{K}^{\mathrm{O}}\right)
\end{aligned}
$$

The evaporative heat transfer coefficient $\mathrm{h}_{\mathrm{e} w \mathrm{~g}}$ between water and glass is given by Zurigat et.al.,(2004), and Shukla and Sorayan (2005), cited by Velmurugan et. al., (2008), as:

$$
h_{e w-g}=\left(16.273 \times 10^{-3}\right) h_{c w-g} \frac{P_{w}-P_{g}}{T_{w}-T_{g}} \quad \rightarrow(2)
$$

The convective heat transfer coefficient between water and glass $h_{c w-g}$ is given by Zurigat et. al., (2004) as:

$$
h_{c w-g}=0.884\left[T_{w}-T_{g}+\frac{\left(P_{w}-P_{g}\right)\left(T_{w}+273.15\right)}{268.9 \times 10^{3}-P_{w}}\right]^{\frac{1}{3}}
$$

where $P_{w}$ and $P_{g}$ are the partial pressure in $\left(N / \mathrm{m}^{2}\right)$ for water vapor at water and the interior glass surface temperature within the still, respectively, which are given by Fernandez and Chargoy (1990), cited by Radwan et.al. (2009), as: 
PROCESS ENGINEERING

$$
\begin{array}{ll}
P_{w}=\exp \left[25.317-\left(\frac{5144}{T_{w}}\right)\right] & \rightarrow(4) \\
P_{g}=\exp \left[25.317-\left(\frac{5144}{T_{g i}}\right)\right] & \rightarrow(5)
\end{array}
$$

But, the rate of distilled water $(\mathrm{m})$ produced by the unit area of the cover depends on the time of the day, and its instantaneous value is given as the follows:

$$
m=\frac{q_{e w-g}}{L_{w}} \quad \Rightarrow \quad q_{e w-g}=m \times L_{w} \quad \rightarrow(6)
$$

By substituting from equation (6) into (1), the thermal instantaneous efficiency of solar still can be rewritten as follows:

$$
\begin{gathered}
\qquad \eta_{i}=\frac{m \times L_{w}}{I(t)} \rightarrow(7) \\
\Rightarrow \quad \eta_{i}=\frac{\text { productivity within time int erval } \times \text { water latent heat of evaporation }}{\text { solar radiation within time int erval }} \rightarrow(8)
\end{gathered}
$$

Therefore, and according to Heamdan et. al. (1999), Badran et. al., (2005), Radwan et. al. (2009), El-Zahaby et. al. (2009) and Kumar and Tiwari (2010), the expressions for operational thermal efficiency of the solar still may be written as:

a) passive solar still (solar still alone)

1. the hourly thermal efficiency

$$
\eta_{\text {passive } h}=\frac{\left(m \times 10^{-3}\right) \rho_{w} L_{w}}{A_{s} I_{s}(t) \times 3600}
$$

2. the daily thermal efficiency

$$
\eta_{\text {passive, }}=\frac{\sum\left(m \times 10^{-3}\right) \rho_{w} L_{w}}{A_{s} \sum I_{s}(t) \times 3600} \quad \rightarrow(10)
$$

b) active solar still ( solar still connected to flat plate collector)

1- the hourly thermal efficiency 


$$
\eta_{\text {active },}=\frac{\left(m \times 10^{-3}\right) \rho_{w} L_{w}}{A_{s} I_{s}(t) \times 3600+A_{c} I_{c}(t) \times 3600}
$$

2- the daily thermal efficiency

$$
\eta_{\text {active }, d}=\frac{\sum\left(m \times 10^{-3}\right) \rho_{w} L_{w}}{A_{s} \times \sum I_{s}(t) \times 3600+A_{c} \times \sum I_{c}(t) \times 3600}
$$

Where:

$\mathrm{m} \quad$ is the hourly productivity, $(\mathrm{mL} / \mathrm{h})$.

$\mathrm{L}_{\mathrm{w}} \quad$ is the latent heat of vaporization at the saturation temperature $\mathrm{T}_{\mathrm{w}}$, $(\mathrm{kJ} / \mathrm{kg})$.

$\mathrm{A}_{\mathrm{s}} \quad$ is the area of the solar still $\quad\left(\mathrm{m}^{2}\right)$.

$A_{c} \quad$ is the area of the solar collector $\quad\left(\mathrm{m}^{2}\right)$.

$\mathrm{I}_{\mathrm{s}}(\mathrm{t}) \quad$ is the solar flux on the inclined glass cover of the solar still $\left(\mathrm{W} / \mathrm{m}^{2}\right)$.

$I_{c}(t) \quad$ is the solar flux on the inclined glass cover of the collector $\left(\mathrm{W} / \mathrm{m}^{2}\right)$.

$\rho_{w} \quad$ is the density of water (assumed to be $1000 \mathrm{~kg} / \mathrm{m}^{3}$ ).

$\mathrm{L}_{\mathrm{w}}(\mathrm{kJ} / \mathrm{kg})$ may be expressed as :

$$
L_{w}=2.4935 \times 10^{3}\left(1-9.4779 \times 10^{-4} T+1.3132 \times 10^{-7} T^{2}-4.7974 \times 10^{-9} T^{3}\right) \rightarrow(13)
$$

The total solar flux on an inclined surface $I(t), I_{s}(t)$ or $I_{c}(t)$, obtained from Srithar et. al.,(2003), and Srithar and Mani (2004), cited by Velmurugan et al., (2008), as the following :

$$
I(t)=\left(I_{g}-I_{d}\right) \frac{\cos \left(\theta_{i}\right)}{\cos \left(\theta_{h}\right)}+I_{d} \frac{1+\cos \beta}{2}
$$

Where:

$I_{d}=$ diffuse radiation intensity on a horizontal surface, $\left(\mathrm{W} / \mathrm{m}^{2}\right)$

$\mathrm{I}_{\mathrm{g}}=$ global radiation intensity on a horizontal surface, $\left(\mathrm{W} / \mathrm{m}^{2}\right)$

$\beta=$ surface inclination, (deg.)

$\theta_{\mathrm{i}}=$ incidence angle on an inclined surface, (deg.) 
$\theta_{\mathrm{h}}=$ incidence angle on a horizontal surface, (deg.)

$\mathrm{I}(\mathrm{t})=$ solar flux on an inclined surface, $\left(\mathrm{W} / \mathrm{m}^{2}\right)$.

To apply equation (14), the hourly global (total) radiation intensity on a horizontal surface $\mathrm{I}_{\mathrm{g}}$ located at Cairo zone $\left(\phi=30^{\circ} \mathrm{N}\right)$ was obtained from Cairo Weather Station of Egyptian Meteorological Authority, while $\cos \theta$ and $\mathrm{I}_{\mathrm{d}}$ were estimated using the equations and correlations that were given by Howell et.al., (1982) and Elsayed et. al., (1994) as:

a) Calculation of the incidence angle on an inclined surface $\theta_{i}$, and on horizontal surface $\theta_{\mathrm{h}}$ :

$\delta=23.45 \sin \left[360\left(\frac{284+n}{365}\right)\right]$

$\omega=15(t-12)$

$\sin \alpha_{s}=\sin \phi \sin \delta+\cos \phi \cos \delta \cos \omega$

$\sin \gamma_{s}=\frac{\cos \delta \sin \omega}{\cos \alpha_{s}}$

$\cos \theta_{i}=\cos \left(\gamma_{s}-\gamma_{c}\right) \cos \alpha_{s} \sin \beta+\sin \alpha_{s} \cos \beta$

for a surface facing the equator, for which $\gamma_{c}=0$

$\cos \theta_{i}=\cos \gamma_{s} \cos \alpha_{s} \sin \beta+\sin \alpha_{s} \cos \beta$

for a surface facing the equator and horizontal, for which $\gamma_{c}=0$ and $\beta=0$ $\cos \theta_{h}=\sin \alpha_{s}$

Where:

$\delta=$ declination angle (deg).

$\mathrm{n}=$ day number counted from January 1 each year.

$\alpha_{\mathrm{s}}=$ solar altitude angle(deg.).

$\phi=$ latitude angle ( $\phi=30^{\circ}$ for Cairo zone $)$.

$\omega=$ hour angle (deg.).

$\mathrm{t}=$ the solar time measured from midnight $($ at solar noon $\mathrm{t}=12)$

$\gamma_{\mathrm{s}}=$ solar azimuth angle(deg.).

$\gamma_{\mathrm{c}}=$ surface azimuth angle(deg.).

$\beta=$ surface tilt angle from horizontal $\left(\beta=30^{\circ}\right)$.

$\theta_{\mathrm{i}}=$ solar beam incident angle relative to a tilted surface (deg.)

$\theta_{\mathrm{h}}=$ solar beam incident angle relative to a horizontal surface, (deg.) 
b) To estimate the hourly diffuse radiation $\left(\mathrm{I}_{\mathrm{d}}\right)$ dependant on the local hourly global (total) radiation measurements (Ig), the generalize correlation that was given by Spencer (1982), cited by Elsayed et. al., (1994), for various parts of the world, could be used. It relates the ratio of hourly diffuse radiation to hourly global (total) radiation $\left(\mathrm{I}_{\mathrm{d}} / \mathrm{Ig}\right)$ to the ratio of hourly global (total) radiation to hourly extraterrestrial radiation ( $\mathrm{Ig} / \mathrm{Io})$ as the following:

$I_{o}=\frac{12 \times 3600}{\pi} G_{s c}\left(1+0.033 \cos \frac{360 n}{365}\right)\left[\frac{\pi}{180}\left(\varpi_{2}-\varpi_{1}\right) \sin \phi \sin \delta+\cos \phi \cos \delta\left(\sin \varpi_{2}-\sin \varpi_{1}\right)\right] \rightarrow(22)$

Where: $\mathrm{G}_{\mathrm{sc}}$ is the solar constant $=1353 \mathrm{~W} / \mathrm{m}^{2}$

$\omega_{1}$ and $\omega_{2}$ are the hour angles at the starting and ending of the hour period.

Then, the correlation has the the following form :

$$
\begin{aligned}
& \frac{I_{d}}{I_{g}}=a \\
& , \quad 0<\frac{I_{g}}{I_{o}}<0.35 \\
& =b-c\left(\frac{I_{g}}{I_{o}}\right) \quad, \quad 0.35 \leq \frac{I_{g}}{I_{o}} \leq 0.75 \quad \rightarrow(24) \\
& =d \quad, \frac{I_{g}}{I_{o}}>0.75
\end{aligned}
$$

where

$$
\begin{aligned}
& b=0.940+0.01180\left|\phi \times \frac{\pi}{180}\right| \\
& c=1.185+0.01350\left|\phi \times \frac{\pi}{180}\right| \\
& a=b-0.3 c \\
& d=b-0.75 c
\end{aligned}
$$




\section{RESULTS AND DISCUSSION}

\section{1-Hourly Variation of the Total Solar Intensity and Ambient Temperature:}

Fig. (2) shows the hourly variation of the total solar intensity $\left(I_{g}\right)$ on horizontal surface and ambient temperature $\left(\mathrm{T}_{\mathrm{amb}}\right)$ prevailing in the testing location on Aug.17,2011.It is clear that the total intensity of solar radiation $\left(\mathrm{I}_{\mathrm{g}}\right)$ gradually increased with time which peaked at noon and reduced towards the evening. It reached the maximum value of 3.303 $\mathrm{MJ} / \mathrm{m}^{2}$ at noon. The ambient temperature $\left(\mathrm{T}_{\mathrm{a}}\right)$ was at its minimum value of 26.2 at 7 a.m. and it has reached the maximum value of about $35 \mathrm{C}^{\circ}$ in the afternoon hours. The above two parameters were purely based on the local climatic conditions of the particular day.

\section{2-Hourly Variation of Temperatures:}

The hourly variation of different temperatures in the active solar still and the solar flux on the inclined glass surface of still cover $\left(I_{\mathrm{s}}\right)$ on Aug.17, 2011 are shown in fig. (3).They represented typical experimental results for 12 hours duration (from 7a.m. to 6 p.m.), during the daylight hours. It is obvious that all temperatures showed similar trends of increasing with the increase of solar radiation during the daylight time. In general, the inlet temperature of the heat

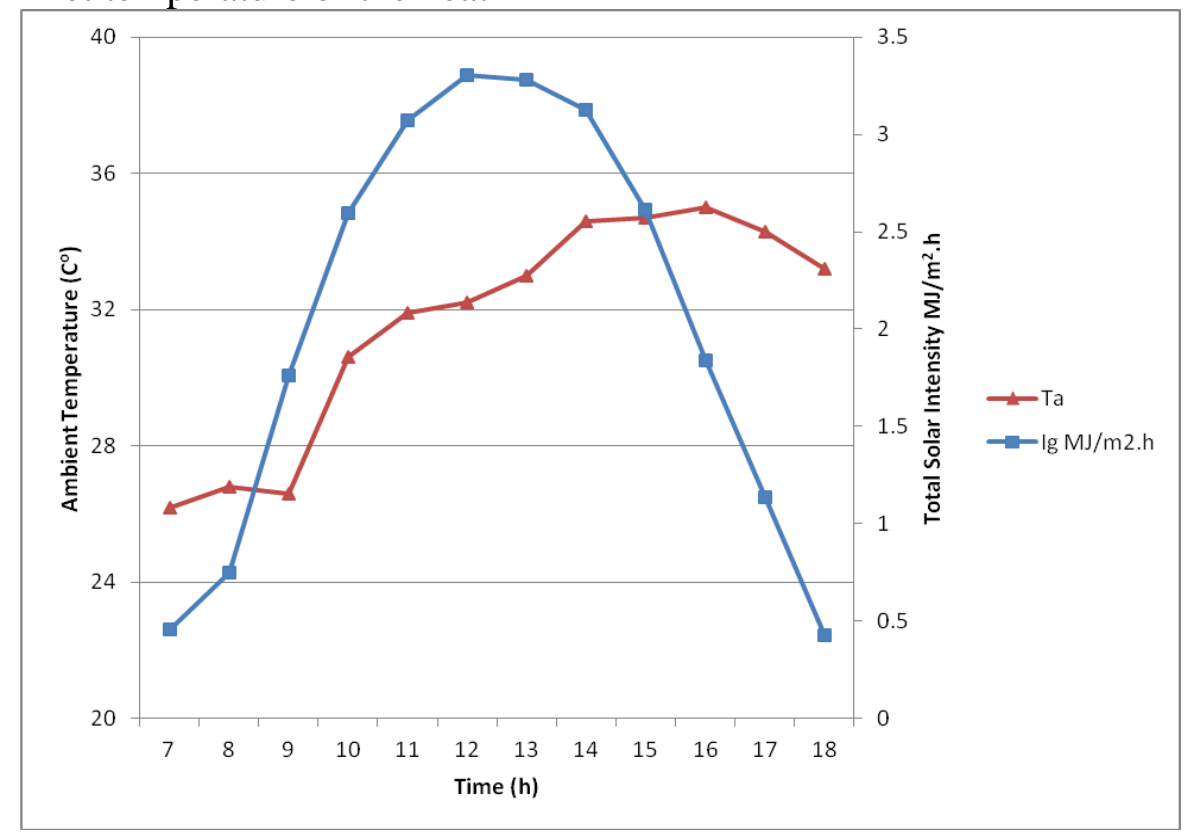

Fig. (2): Variation of the total solar intensity and ambient temperature. 
exchanger $\mathrm{T}_{\text {exi }}$ was the highest then followed by the outlet temperature of the heat exchanger $T_{\text {exo }}$, basin water temperature $T_{w}$, vapor temperature $\mathrm{T}_{\mathrm{v}}$, inside glass temperature $\mathrm{T}_{\mathrm{gi}}$, outside glass temperature $\mathrm{T}_{\mathrm{go}}$, and ambient temperature $T_{a}$. The average basin water temperature (which is the main parameter that affects the productivity) of the active solar still reached the highest value of about $66 \mathrm{C}^{\circ}$ during the period from 1 until 2 p.m. on Aug. 17, 2011, while it was $56 \mathrm{C}^{\mathrm{o}}$ for the still alone on Aug. 16, 2011.The temperature of the inner glass cover of the active solar still is higher than the outer glass temperature, as mentioned previously. This is due to the release of more heat of condensation on the inner surface of glass cover. The results have also showed that at the beginning of the daylight hours, there is a slight increase in the temperature of the outer glass surface comparing with the temperature of the inner glass surface of the solar still. This could be due to low intense solar radiation at that period. It can be further seen that the basin water temperature $\left(T_{w}\right)$ at water depth of $0.5 \mathrm{~m}$ is higher than the basin temperature $\left(\mathrm{T}_{\mathrm{b}}\right)$ unlike in passive solar still that is due to transfer extra thermal energy to the basin water of the solar still from the flat-plate collector through the heat exchanger.

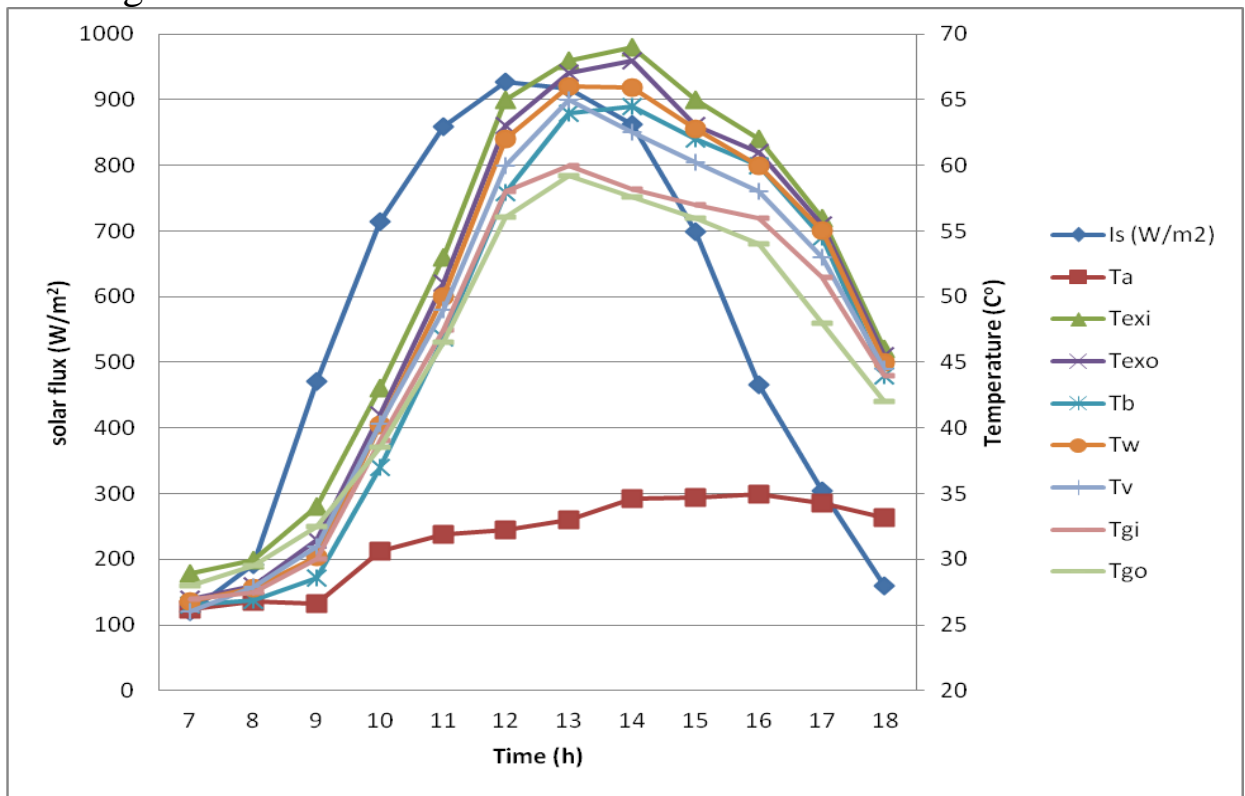

Fig. (3): Hourly variation of different temperatures and the solar flux on an inclined glass surface of the active solar still. 


\section{3-Still Productivity:}

The typical experimental results of the hourly and accumulated productivity are shown in figs. 4 and 5, respectively. They obtained during the daylight hours ( 7 a.m. - 6 p.m.) from the passive solar still (still alone) on Aug. 16, 2011 (which is the recommended characteristic day for the average daily extraterrestrial insolation of Aug. month, Howell, et. al., 1982) and active solar still on Aug. 17, 2011. During that duration (7 a.m. - 6 p.m. $)$, the average measured wind speed was in the range of $(0.45$ $0.3 \mathrm{~m} / \mathrm{s}$ ), while the average measured relative humidity was in the range of $(58 \%-33 \%)$. The effect of connecting the flat plate collector to the solar still on the still productivity is clearly shown in figs. (4 and 5). There was a considerable increase in the productivity of the active solar still over that of the still alone where the productivity of the active solar still was $3730 \mathrm{~mL} / \mathrm{m}^{2}$ during the daylight hours, and it was $1990 \mathrm{~mL} / \mathrm{m}^{2}$ in the absence of the flat plate collector. This is due to supplying additional heat energy to the basin water form the collector to increase its temperature and, of course, increase the temperature difference between the basin water and inner glass temperature which is the main parameter that affects the still productivity. The observations also

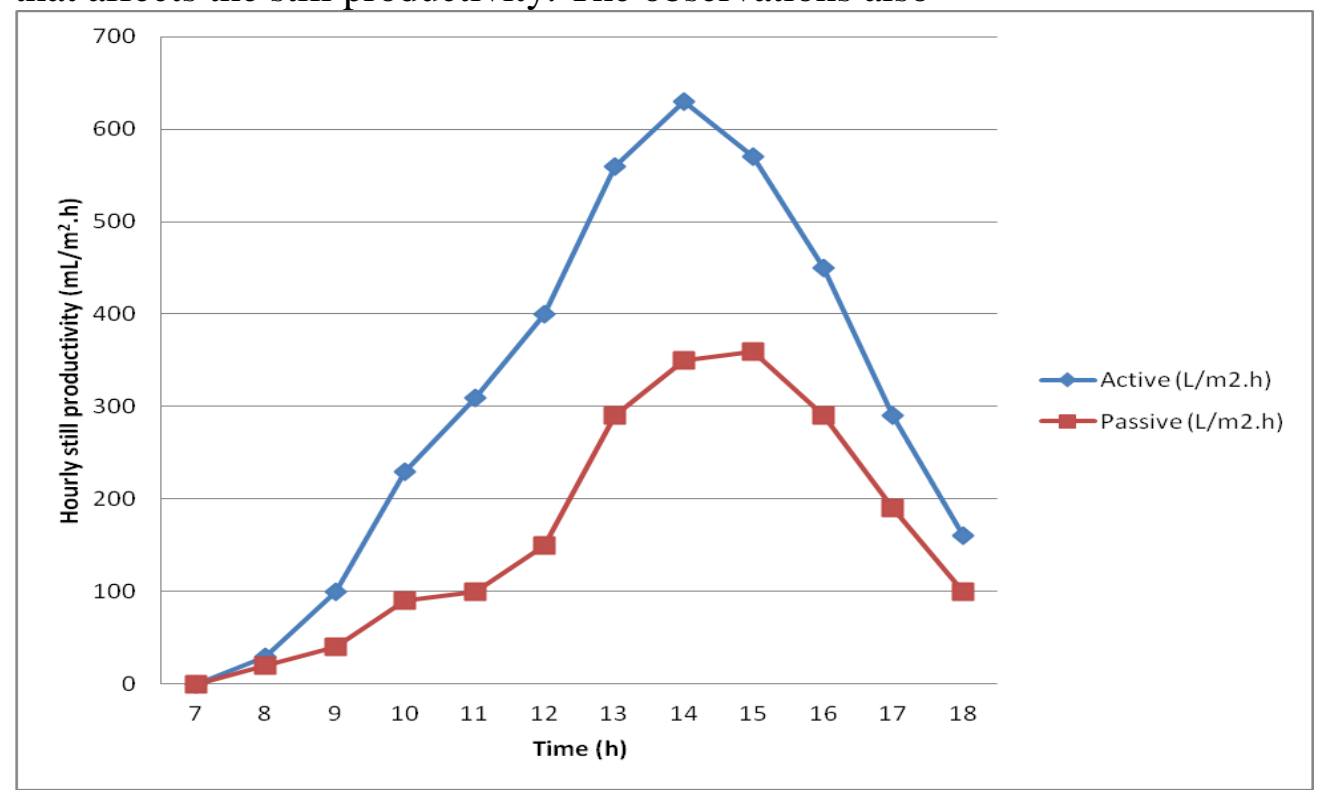

Fig. (4): Effect of connecting the solar still to the flat-plate collector on the hourly still productivity. 


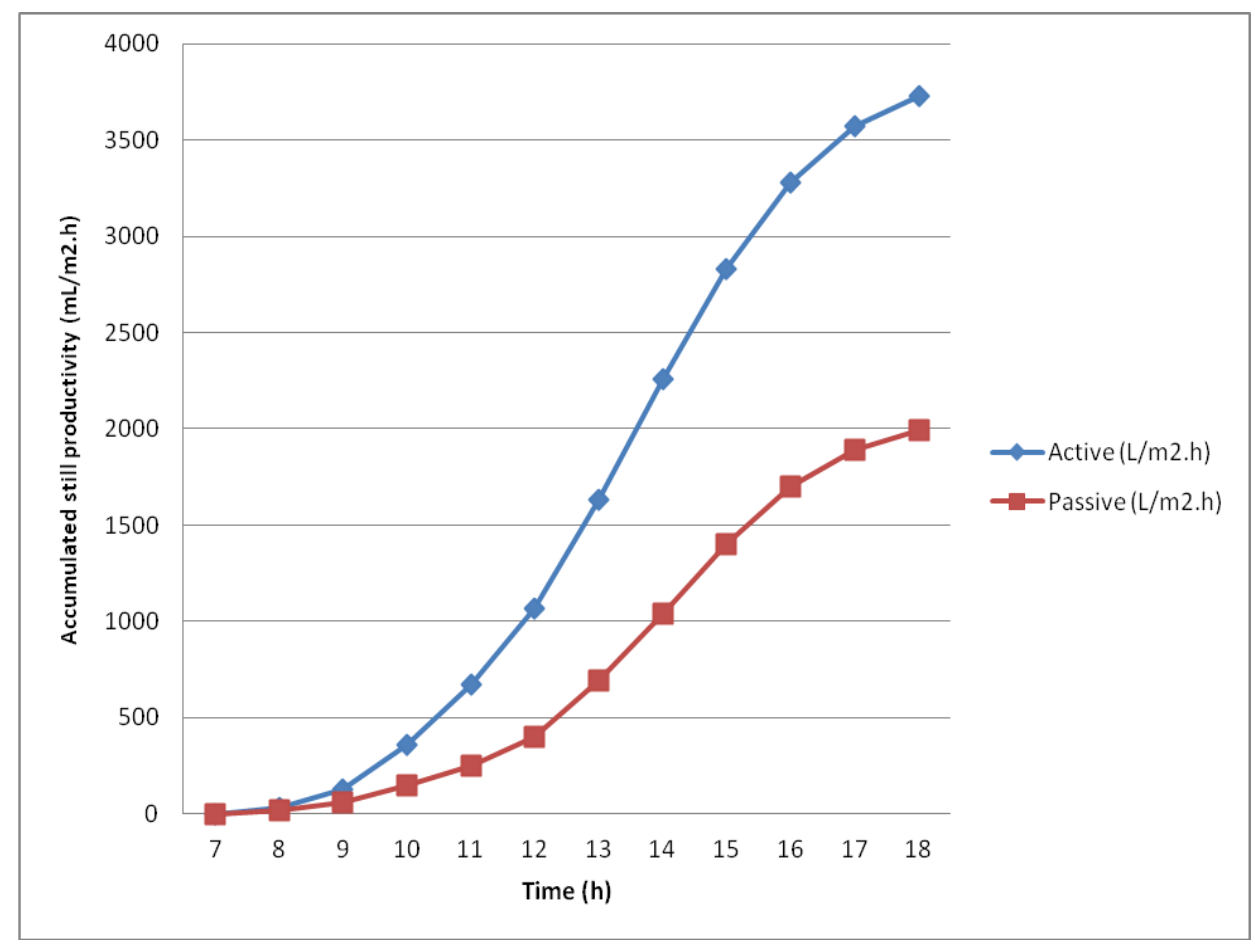

Fig. (5): Effect of connecting the solar still to the flat-plate collector on the accumulated still productivity.

showed that the hourly yield increased with the increase in solar radiation. However, there was time difference between maximum solar flux on the inclined surface of the still and collector cover and maximum distillate yield to occur. The maximum solar flux was at $1200 \mathrm{~h}$ on the still and collector surface on Aug. 17, 2011, while the maximum distillate yield occured at $14.00 \mathrm{~h}$ due to time lag between evaporation and condensation as well as storage effect in the active solar still. It was also observed that the distillation was continued during the night. This is due to remaining the basin water hot enough after sunset as a result of storage effect in the solar still. The yield obtained (during the period from 7 p.m. to 6 a.m.) from the active and passive solar still was about $450 \mathrm{~mL} / \mathrm{m} 2$ and $300 \mathrm{~mL}$ $/ \mathrm{m}^{2}$, respectively. So, the daily yield obtained from the solar still with flat plate collector and still alone was $4.180 \mathrm{~L} / \mathrm{m}^{2}$.day and $2.290 \mathrm{~L} / \mathrm{m}^{2}$.day, respectively, as shown in fig. (6). The daily production rate was increased by about $45.22 \%$ after connecting the solar still to the flat plate collector. It was about 1.83 times higher than the productivity obtained from the 
still alone. The average daily production rate of July, 2011 for the active and passive solar still was found $3.850 \mathrm{~L} / \mathrm{m}^{2}$.day and $2.150 \mathrm{~L} / \mathrm{m}^{2}$.day, respectively(about $44.16 \%$ increasing), while in Sept., 2011, it was 3.050 $\mathrm{L} / \mathrm{m}^{2}$ day and $1.850 \mathrm{~L} / \mathrm{m}^{2}$ day, respectively (about $39.34 \%$ increasing).

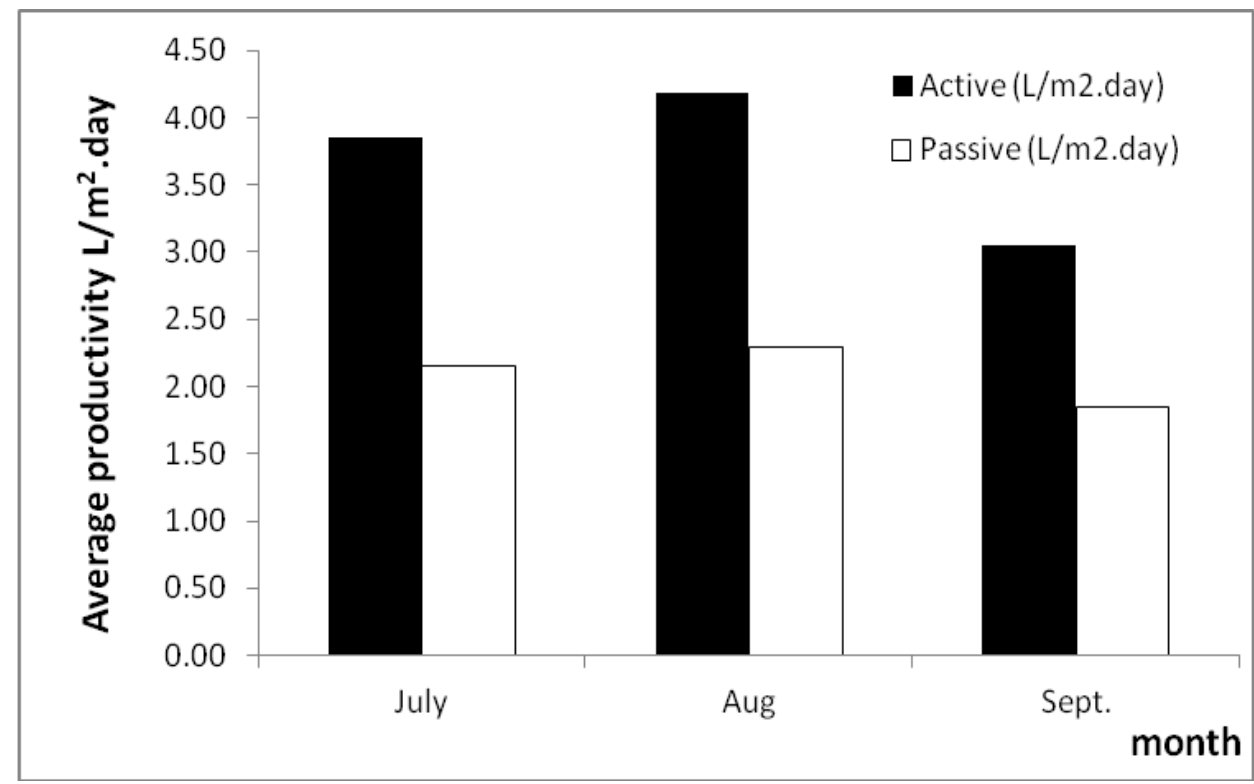

Fig. (6): The average daily production rate in July, Aug. and Sept., 2011

\section{4-Still Thermal Efficiency :}

Equations ( 9 to 14) have been used to evaluate the thermal efficiency of the passive and active solar still. In general, the results showed that despite the higher productivity of the active solar still, its thermal efficiency was less than the passive solar still. This is due to high operating temperature range and, consequently, large thermal losses in active solar still. The results showed that the average daily thermal efficiency of the passive solar still was $23.1 \%$ for $0.05 \mathrm{~m}$ water depth on Aug.16, 2011, while in case of active solar still; this value has been reduced to 19.2\% on Aug., 17, 2011 for the same water depth. That is almost 3.9\% lower than the passive solar still which represented a slight decrease below the thermal efficiency of the still alone. 
PROCESS ENGINEERING

\section{5-Economic Analysis :}

The payback period of the experimental setup depends on overall manufacture cost, maintenance cost, cost of feed water, operating cost (Velmurugan et. Al., 2008), and cost of the required electric power for turning the pump. So, the economic analysis, according to the current Egyptian conditions, was estimated as the following:

Overall manufacture cost (investment) $=$ EGY 1800, $(\$ 1.0=6$ EGY $)$.

Maintenance cost

Operating cost
$=$ EGY 0.60/day.

$=$ EGY 0.60/day.

Cost of feed water is negligible.

The subsidized price of electricity that is given by the government sector is taken as EGP $0.16 / \mathrm{kWh}$, then

Cost of the required electric power for turning the pump

$=(0.0132 \mathrm{kWh} /$ day $)(0.16 \mathrm{EGP} / \mathrm{kWh})=\mathrm{EGY} 00.0021 /$ day

The average productivity of the active solar still of the three months (July, Aug. and Sept.) = 3.69 lit $/$ day

The price of distilled water $=$ EGP $2.0 /$ lit

The average price of the distilled water production of the active solar still $=(3.69)(2) \quad=$ EGP $7.38 /$ day

Net profit $=$ the price of the produced distilled water - (maintenance cost + operating cost + cost of feed water + cost of the required power for turning the pump)

Net profit $=7.38-(0.6+0.6+0.0+0.0021)=$ EGP $6.178 /$ day

Payback period=Investment/Net profit $=1800 / 6.178=291.36=292$ days

The payback period should be increased over 292 days due to the expected decrease in the active still productivity during the winter season. 


\section{CONCLUSIONS}

Over the past decades, the solar energy was used for water desalination as a renewable and clean source of energy. In this work, an active solar still system is designed, manufactured and tested in Cairo $\left(\phi=30^{\circ} N\right)$, Egypt. The following conclusions have been drawn from the study : the average productivity of the developed passive solar still on Aug. 16, 2011 and the active solar still on Aug. 17, 2011, was about $2.290 \mathrm{~L} / \mathrm{m}^{2}$.day, and $4.180 \mathrm{~L} / \mathrm{m}^{2}$.day, respectively. There was a considerable increase in the productivity of the active solar still where the daily production rate of the active solar still has increased by about $45.22 \%$; it was about 1.83 times higher than the passive solar. That is due to additional thermal energy supplied by the collector to the solar still. It was also found that the thermal efficiency of the active solar still (19.2\%) is lower than the passive solar still $(23.1 \%)$ by an average of $3.9 \%$. The average daily production rate of July, 2011 for the active and passive solar still was found $3.850 \mathrm{~L} / \mathrm{m}^{2}$.day and $2.150 \mathrm{~L} / \mathrm{m}^{2}$.day, respectively( about $44.16 \%$ increasing), while in Sept., 2011 , it was $3.050 \mathrm{~L} / \mathrm{m}^{2}$.day and 1.850 $\mathrm{L} / \mathrm{m}^{2}$.day ,respectively( about $39.34 \%$ increasing). The payback period of the developed active system was 292 days. It should be increased over 292 days due to the decrease of the still production in the winter season as expected. As a future study, a theoretical analysis based on the energy balance equations of different components of the developed active solar still system and numerical solution for prediction the instantaneous performance should be investigated.

\section{REFERENCES}

Abdel-Ghaffar, E. A. M., 1989. Development of a simple passive solar still suitable for new village's houses at the northern western coast of Alexandria. Proceeding of the Egyptian-German Conference, Agric. Mechanization, 4-6 October, Mansura University : 295-310.

Aybar, H. S., 2007. A review of desalination by solar still. Solar Desalination for the $21^{\text {st }}$ Century, 207-214. 
Badran, A. A., A. A. Al-Hallaq, I. A. E. Salman and M. Z. Odat. 2005, A solar still augmented a flat-plate collector, Desalination, 172:227-234.

Badran, O. O. and H. A. Al-Tahaineh, 2005. The effect of coupling a flat-plate collector on the solar still productivity, Desalination, 183:137-142.

El-Shahat S. A., 1999. Utilization of solar energy in agricultural engineering purposes. M.Sc. th., Agric. Mech. Dept., Fac. Of Agric., Kafr El-Sheikh, Tanta Univ., Egypt.

El-Sayed, H.S., 1993. Solar drying of poultry manure for animal feed under simulated Egyptian conditions. Ph.D. th., Agric. Eng. Dept., Fac. Of Agric., Cairo Univ., Egypt.

Elsayed M. M., I. S. Taha and J. A. Sabbagh, 1994. Design of solar thermal systems. Scientific Publishing Centre, King Abdulaziz University, Jeddah, Saudi Arabia. ISBN 9960-06-001-2.

El-Zahaby A.M., A. E. Kabeel, A.I. Bakery, E. Agouz and O.M. Hawam, 2009. Enhancement of solar desalination still productivity using flash evaporation.Thirteenth International Water Technology,IWTC 13, Hurghada, Egypt.

Fernandez, J. L. and N. Chargoy, 1990. Multi stage indirectly heated solar still. Solar Energy, Journal, 44(4): 215-223.

Hamdan, M. A., A. M. Musa and B. A. Jubran, 1999. Performance of solar still under Jordanian climate. Energy Conservation and Management, 40:495-503.

Hou, S., S. Ye and H. Zhang, 2005. Performace optimization of solar humidification-dehumidification desalination process using Pinch technology. Desalination $183: 143-149$.

Howell J. R., R. B. Bannerot and G. C. Vliet , 1982. Solar-thermal energy systems. McGraw-Hill Book Company. ISBN 0-07-0306036. 
Kumar S. and A. Tiware, 2010. Design, fabrication and performance of a hybrid photovoltaic/thermal (PV/T) active solar still. Energy Conversion and Management, 51:1219-1229.

${ }^{(*)}$ Pure Water for the World. Water every where but not a clean drop to drink. Inf @ purewaterfortheworld.org., Fax 802-773-8575.

Radwan, S. M., A. A. Hassanain and M. A. Abu-Zeid, 2009. Single slope solar still for sea water distillation. World Applied Sciences Journal, 7(4): 485-497.

Sayigh,A. A. M.,1977. Solar energy engineering. $1^{\text {st. }}$ Ed., academic press.

Shukla, S. K. and V. P. S. Sorayan, 2005. Thermal modeling of solar still, an experimental validation. Renewable Energy, 30(5) :683699.

Spencer, J. W.,1982. A comparison of methods for estimating hourly diffuse solar radiation from global solar radiation. Solar Energy 29:19-32.

Srithar, K. and A. Mani, 2003. Comparison between simulated and experimental performance of an open solar flat plate collector for treating tannery effluent. Int. Comm. Heat Mass Transfer, 30(4):505-514.

Srithar, K. and A. Mani, 2004. Analysis of a single cover FRE flat plate collector for treating tannery effluent. Applied Thermal Engineering, 24(5-6):873-883.

Tiwari, G. N. and A.A.M. Sayigh ,2002. Solar Energy. Narosa Publishing House, New Delhi, India.

Velmurugan V., S. Kumaran, V. N. Prabhu, and K. Srithar,2008. Productivity enhancement of stepped solar still - performance analysis. Thermal Science, 12(3):153-163.

Voropoulos, K., E. Mathioulakis and V.Belessiotis, 2001. Experimental investigation of a solar still coupled with solar collectors. Desalination, 138:103-110. 
Zurigat, Y. H. and M. K. Abu-Arabi, 2004. Modeling and performance analysis of a regenerative solar desalination unit. Applied Thermal Engineering, 24(7):1061-1072

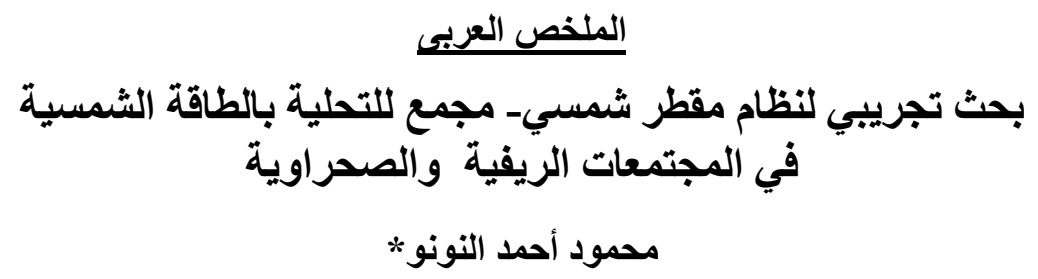

استخدمت الطاقة الثمسية منذ عشرات السنين لتحلية المياه، كمدر نظيف ومتجدد للطاقة، أساليب فعالة متعددة نم تبنيها لتحسين إنتاجية المقطر الثمسي ، ولكن معظم الأعمال البحثية

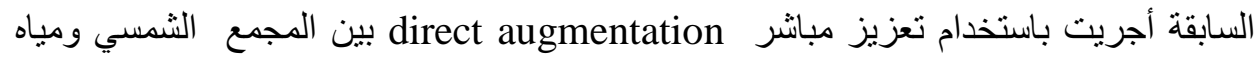

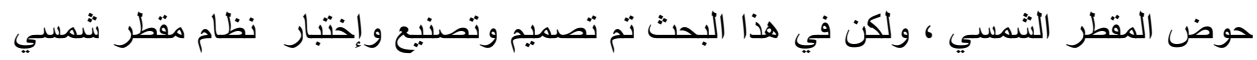

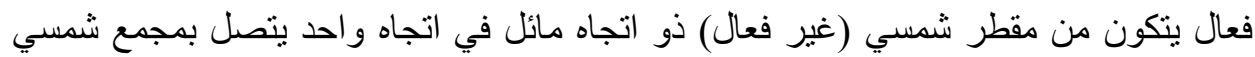

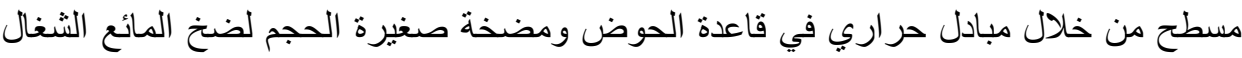
(ماء مقطر) ليسري في دائرة مغلقة ومنفصلة عن مياه حوض المقطر الثمسي بهدف نقل مزيد

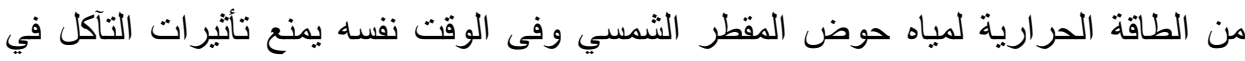

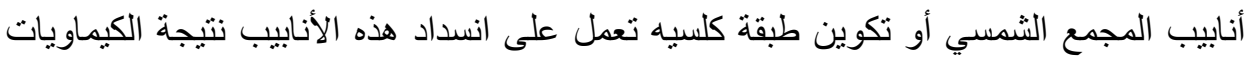

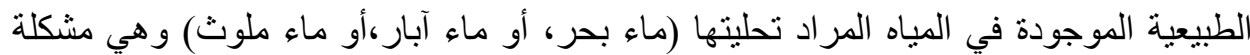

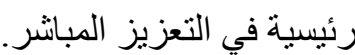
تجارب عديدة أجريت عند 0.05 م ارتفاع ماء حوض المقطروباستخدام ماء مالح (28608ppm)

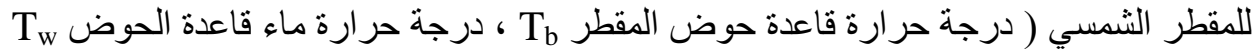

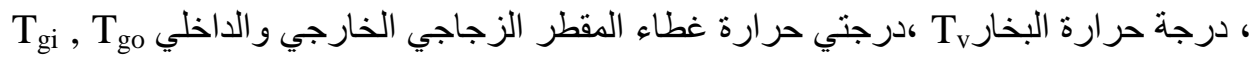

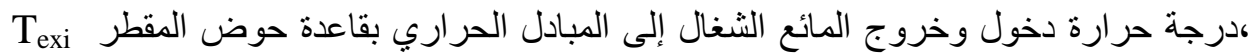

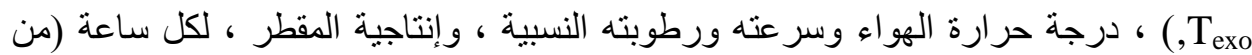

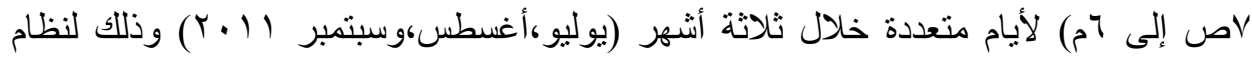

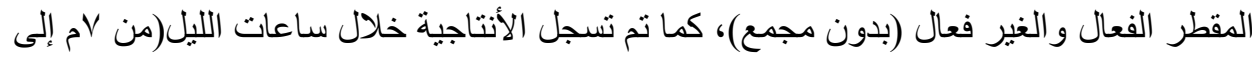

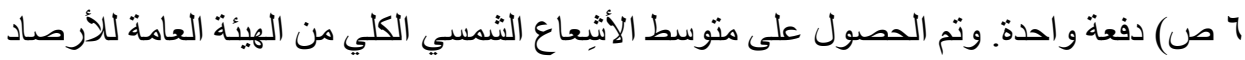

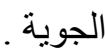

*ققم الهندسة الزراعية_كلية الزراعة_جامعة عين شمس_القاهرة-مصر 


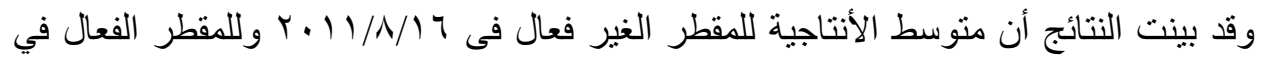

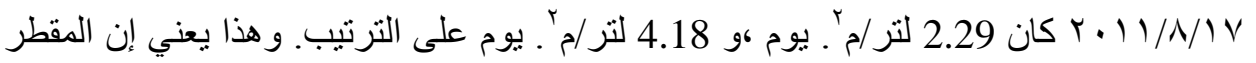

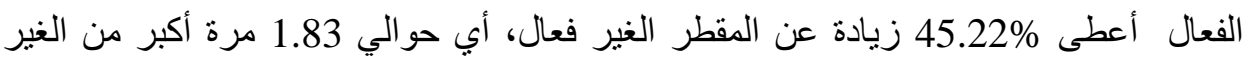

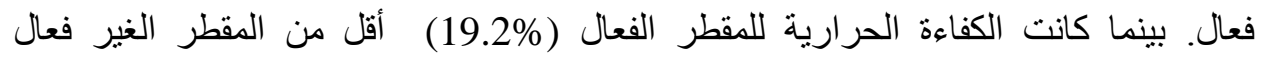
(23.1\%) بمنوسط حوالي 3.9\% ـ وقد بينت النتائج أن منوسط الأنتاجية للمقطر الفعال

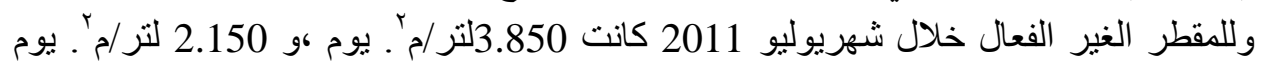

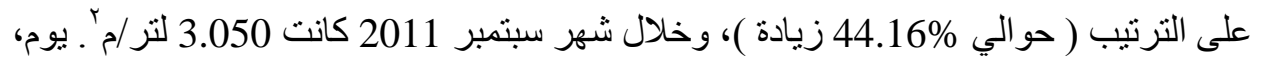

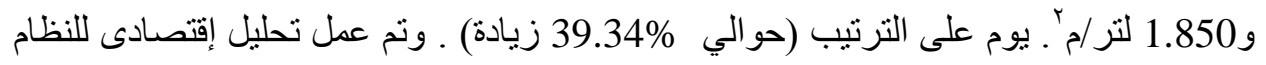

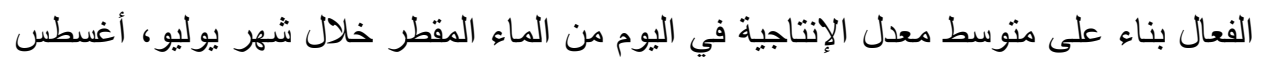

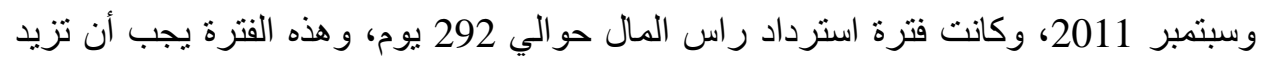
عن 292 يوم بسبب نقص الأنتاجية خلال فصل الثتاء كما هو متوقع. 